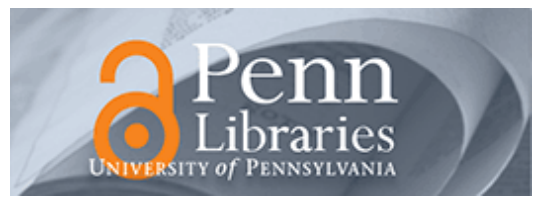

University of Pennsylvania

ScholarlyCommons

Management Papers

Wharton Faculty Research

4-1998

\title{
Informational Regulation of Environmental Risks
}

Paul R. Kleindorfer

University of Pennsylvania

Eric W. Orts

University of Pennsylvania

Follow this and additional works at: https://repository.upenn.edu/mgmt_papers

Part of the Management Sciences and Quantitative Methods Commons

\section{Recommended Citation}

Kleindorfer, P. R., \& Orts, E. W. (1998). Informational Regulation of Environmental Risks. Risk Analysis, 18 (2), 155-170. http://dx.doi.org/10.1111/j.1539-6924.1998.tb00927.x

This paper is posted at ScholarlyCommons. https://repository.upenn.edu/mgmt_papers/260

For more information, please contact repository@pobox.upenn.edu. 


\title{
Informational Regulation of Environmental Risks
}

\author{
Abstract \\ This paper examines the law and economics of informational regulation (IR) of environmental risks. \\ Informational regulation here means regulation which provides to affected stakeholders information on \\ the operations of regulated entities, usually with the expectation that such stakeholders will then exert \\ pressure on these entities to comply with regulations in a manner which serves the interests of \\ stakeholders. As such, IR reinforces and augments direct regulatory monitoring and enforcement through \\ third-party monitoring and incentives. The paper provides two contrasting frameworks, from law and \\ economics, to analyze the costs and benefits likely to arise from IR and concludes with a discussion of \\ the appropriate scope of IR as a substitute for and complement of traditional environmental regulation \\ and law. \\ Disciplines \\ Management Sciences and Quantitative Methods
}




\title{
INFORMATIONAL REGULATION OF ENVIRONMENTAL RISKS ${ }^{\wedge}$
}

\author{
Paul R. Kleindorfer \\ and \\ Eric W. Orts \\ Ref. No. 97-11-37 \\ Paul R. Kleindorfer \\ Universal Furniture Professsor \\ Decision Sciences and Economics \\ Professor of Public Policy and Management \\ The Wharton School \\ . University of Pennsylvania \\ 1328 Steinberg Hall-Dietrich Hall \\ Philadelphia, PA 19104 \\ Eric W. Orts \\ Associate Professor \\ Legal Studies \\ The Wharton School \\ University of Pennsylvania \\ 2202 Steinberg Hall-Dietrich Hall \\ Philadelphia, PA 19104 \\ (215) 898-3018 \\ ortse@wharton.upenn.edu
}

September 25, 1997

1 The authors thank Michael Baram, Jason Johnston, Howard Kunreuther and Irv Rosenthal for comments on an earlier draft of this paper. (Forthcoming in the Journal of Risk Management and Analysis.) 


\title{
Informational Regulation of Environmental Risks
}

\begin{abstract}
This paper examines the law and economics of informational regulation (IR) of environmental risks. Informational regulation here means regulation which provides to affected stakeholders information on the operations of regulated entities, usually with the expectation that such stakeholders will then exert pressure on these entities to comply with regulations in a manner which serves the interests of stakeholders. As such, IR reinforces and augments direct regulatory monitoring and enforcement through third-party monitoring and incentives. The paper provides two contrasting frameworks, from law and economics, to analyze the costs and benefits likely to arise from IR and concludes with a discussion of the appropriate scope of $I R$ as a substitute for and complement of traditional environmental regulation and law.
\end{abstract}

Key words: Informational Regulation, Environmental Risk Management, Transactions Costs, Performance-Based, Specification-Based Regulation, Private rights. 


\section{Introduction}

This paper examines the law and economics of informational regulation of environmental risks. There are a number of recent examples of this kind of regulation. One of the best known is the Toxics Release Inventory, which requires periodic disclosure of industrial releases of certain specified chemicals. ${ }^{1}$ Another example is the use of "eco-labels" to encourage environmental advertising. ${ }^{2}$ A third is the requirement under Section 112(r) of the Clean Air Act Amendments of 1990, for businesses to create and publicly disclose "risk management plans" (RMPs) for accidental chemical releases, including plans for "a worst case scenario." ${ }^{3}$ A fourth is a requirement of annual "consumer confidence reports" to be prepared and disseminated by community water suppliers under the Safe Drinking Water Act Amendments of $1996^{4}$. Finally, the ISO 14000 series of standards represent an international environmental standard, developed by industry and government representatives, to capture broad elements of effective environmental management systems. The ISO 14000 standards are, like eco-labels, voluntary and obtained through certification by accredited third parties ${ }^{5}$. Informational regulation in these various forms aims to achieve higher levels of environmental protection by improving the quality, quantity, and availability of information about environmental harms, benefits, and risks.

A shift toward increasing reliance on informational regulation (or "IR" for short) has begun in the environmental arena ${ }^{(14) 6}$. However, application of $I R$ methods to environmental issues has not been systematic. Unlike other areas of law, such as securities regulation, environmental law has not yet evolved to emphasize disclosure of information as a primary focus. Instead, environmental law has alternated among traditional tort law, modern command-and-control regulations, and other market-based variants. The idea of informational regulation has emerged only recently in a 
piecemeal and inchoate fashion ${ }^{(49)}{ }^{7}$ To an extent, this sort of haphazard regulatory evolution is desirable. It permits useful regulatory experimentation. However, we believe more careful systematic thinking about the legal and economic nature of $\mathrm{IR}$ will yield a better prediction about when this approach is likely to work efficiently and effectively and when it will not ${ }^{8}$.

Although this paper makes some tentative prescriptive recommendations concerning the likely usefulness of $\mathrm{IR}$, its primary task is descriptive. In the next section 2 , we provide some background on informational regulation as it relates to other broad categories and conceptions of regulation. In section 3 , we set forth an economic model of $\mathbb{R}$. In section 4 , we describe $\mathbb{R}$ from a legal perspective. We return to prescriptive themes in section 5 and discuss when policymakers should choose regulatory approaches emphasizing IR rather than traditional approaches. Section 6 is by way of conclusion.

\section{Defining Informational Regulation}

Most environmental statutes regulate environmental performance directly. These statutes and the regulations which implement them do so either in the form of output performance standards or in the form of technology or process specifications. We refer to the former type of regulation as performance-based and the latter as specification-based. For example, a statute may set emissions levels for certain pollutants (performance-based), mandate specific pollution-control technologies (specification-based), or require environmentally protective designs or procedures (also specification-based). In whatever form, performance-based and specification-based regulations depend on setting standards and then enforcing them. ${ }^{9}$ In this sense, performance-based and specification-based standards rely on "command-and-control." The relationship between the 
regulating agency and regulated entity is direct, as indicated in Figure 1, although there is room for negotiation between the regulators and the regulated firm with respect to both standard setting (negotiated rulemaking) and enforcement (negotiated settlements). ${ }^{10}$

[Figure 1 about here.]

Informational regulation is any regulation which provides to third parties information on company operations. IR can therefore complement either performance-based or specification-based regulation. For example, requiring the publication of certain information may provide a verified signal of regulatory compliance. Alternatively, $\mathbb{R}$ can require that specified third parties or the public have access to certain information about a company's operations, without mandating a particular regulatory result or outcome. As we describe more fully in sections 3 and 4 below, $\mathbb{R}$ comes in different forms to address different problems. For example, the Toxic Release Inventory and Risk Management Plans under Section 112(r) of the Clean Air Act require governmentmandated informational reporting. Eco-labels, on the other hand, may involve governmental standards -- although independent private standards may also be employed ${ }^{11}$-- but they usually are not mandatory in the sense that all consumer products of a certain sort must carry an eco-label. ${ }^{12}$ Our point is that $\mathbb{R}$ also involves standards, even though "enforcement" of them may be indirect. Sometimes it is not the government that "enforces" the standards in an IR system, but rather economic markets, citizen groups, or public opinion. These non-governmental powers supply "regulatory" pressure through market dynamics, private litigation, or moral persuasion. In addition, IR may involve the creation and development of non-governmental standards of acceptable behavior. The relationship among standards, the regulator and regulated, and economic markets 
and public opinion in $\mathrm{IR}$ is shown schematically in Figures $2 \mathrm{~A}$ and $2 \mathrm{~B}$.

[Figures $2 \mathrm{~A}$ and $2 \mathrm{~B}$ about here.]

The main point to be made about these figures is that a focus on informational disclosure opens up the traditional bilateral relationship between the regulator and the regulated to include other social institutions, most importantly, economic markets and public opinion. Professional institutions that serve as standard-setting bodies may also have a central role in IR.

Note that specification and performance standards do not disappear in IR; they rather play three different possible roles. Under option 1 of Figure $2 B, \mathbb{R}$ enhances traditional forms of performance-based or specification-based regulation. IR adds a mechanism of enforcement: both mandating disclosure of information about whether the underlying regulatory standards are being met and providing an investigative tool for enforcement authorities. ${ }^{13}$ In option 1, IR eases the task of direct regulation by providing for self-reporting about compliance. Of course, this additional burden of informational disclosure also increases compliance costs of the performance-based or specification-based regulation.

Option 2 of Figure 2B illustrates a different form of $I R$, which off-loads the task of setting and policing standards to professional third-party organizations, perhaps with some oversight of the process by government. ${ }^{14}$ A number of variations are possible. For example, standards might be conditioned on approval of the regulator, although primary responsibility for the development of standards could remain with a third-party organization. Or procedures for consultation with public interest groups about standards might be adopted in an option 2 system. The important distinction between option 2 and option 1 is the mode of "enforcement" of the standards. Option 2 relies on 
non-governmental punitive actions -- such as decertification or other formal disapproval of a firm's products or practices -- and the adverse effects this negative action has on public opinion and economic markets of concern to the firm. These expressions of disapproval could also harm the firm in private lawsuits that may arise from accidents, providing evidence of negligence, or supporting claims of negligence per se. ${ }^{15}$

Like option 2, option 3 relies on public opinion and the market, but the standards applied originate from within the firm itself. The Responsible Care program of the Chemical Manufacturers Association is a salient example of an industry-generated standard. ${ }^{16}$ Another example is the set of principles of the non-profit Coalition for Environmentally Responsible Economies (CERES) $)^{(60)}$. A further example of growing importance is the ISO 14000 standards which are intended to be verified by accredited third parties. For an option 3 system to work effectively from a regulatory perspective, some sort of monitoring and disclosure system is needed with its own set of procedural standards to assure that the standards are meaningful and that certification under such standards represents compliance with the standard.

With respect to environmental standards themselves, a business firm looks for two types of rewards. The first relates to what we call the firm's "economic franchise," namely, the continued profitability to allow the firm to prosper or at least to remain viable. If a firm fails to satisfy its economic raison d'etre, it loses its economic franchise and falls into bankruptcy or dissolution. The second reward, which intertwines in many respects with the first, relates to what we call the "social franchise." ${ }^{17}$ Businesses pursue their economic objectives within constraints imposed by society ${ }^{(34)}$. Primary among the social constraints on business are those imposed by law. Violation of legal standards risks significant economic costs in terms of civil and punitive fines. In addition, violation of law, particularly criminal law, risks very serious personal and moral costs. Beyond the confines 
of law are independent considerations of business ethics. A business firm, composed of people, not just balance sheets, must legitimate itself as a legal and moral entity if it is to continue to enjoy its social franchise without undue interference from its employees, customers, and neighbors.

In terms of these two kinds of rewards, conventional regulation focuses on the economic calculations of businesses. It aims to influence the calculations of the economic franchise by imposing civil fines to counterbalance any economic gain achieved by cutting corners on legal standards. ${ }^{18}$ Only through the heavy-handed method of criminal prosecution does this method of regulation significantly challenge a firm's claim to its social franchise, although very heavy civil penalties may have a similar effect.

In contrast, IR opens up possibilities of influencing the economic and social franchises more broadly and more subtly. Dissemination of information about environmental performance can influence public opinion, which can affect a business's social franchise as well as its economic franchise. In an approach emphasizing $\mathbb{R}$, rewards and punishments for environmental performance are given to businesses not just by government, but by economic markets and the public opinion of society-at-large and of smaller communities related directly to the firm, such as boards of directors or key professional organizations of employees. ${ }^{19}$

This introductory description illuminates the choice of regulatory strategies and the considerable number of options available. We now consider the benefits of $\mathrm{R}$ in regulatory design from the perspective of two descriptive accounts of the problem: first from the perspective of economics, and then of law. 


\section{Economic Models of Informational Regulation}

All economic models of regulation are concerned in some way with information, but informational regulation in the sense defined here has not received much attention in economics. The traditional economic treatment of information is illustrated by Dasgupta et al. ${ }^{(12)}$ and other work reviewed in Gruenspecht and Lave ${ }^{(17)}$. The essence of this traditional work is that the regulator does all the monitoring and enforcement. In contrast, we emphasize the involvement of the public and third parties.

To illustrate, we consider the Kambhu ${ }^{(31)}$ and $\mathrm{Kim}{ }^{(33)}$ framework, which embodies various models for predicting the response of a firm to standards-based regulation. This framework is in the spirit of Steven Shavell's earlier work (1984). The basic model considers the effort (denote the monetary value of this effort by $\mathrm{x}$ ) expended by a rational firm when the firm faces the following lottery as a result of this effort:

\section{Accident Lottery Resulting from Effort Level $\mathrm{x}$}

With probability $\mathrm{P}(\mathrm{x})$ an accident results with loss $\mathrm{L}(\mathrm{x})$.

With probability 1-P(x) no accident and no loss occurs.

The expected social cost $\mathrm{S}(\mathrm{x})$ of the firms' expending effort $\mathrm{x}$ is then given by:

$$
S(x)=x+P(x) L(x) \text {. }
$$

The object of regulation is to motivate the firm to choose an $\mathrm{x}$ to minimize $\mathrm{S}(\mathrm{x})$. If the firm expects liabilities different from $P(x) L(x)$, then the firm will not choose the socially optimal level of effort, but rather a level of effort which minimizes the expected liabilities the firm actually faces.

Shavell ${ }^{(58)}$ and others have studied various institutional arrangements (e.g., strict liability) 
for ensuring that the firm internalizes the full social cost of its actions and therefore undertakes the efficient level of effort $x$. Information enters into this problem in various ways. Typically, the regulator establishes a standard $x_{s}$, which is a floor on required effort by the firm. In doing so, the regulator may be imperfectly informed about the firm-specific expected losses $P(x) L(x)$ and has to weigh this imperfect level of information against the social costs of under- or over-compliance resulting from the regulatory standard in relation to the social optimum. ${ }^{20}$ If a uniform standard is to be enforced, further losses may result from the heterogeneity of firm-specific mitigation costs in the face of such a uniform standard. Other losses may result because the regulator may not be able to observe precisely what the firm's effort is. In addition, there may be incomplete enforcement so that firms violating the required performance standard may go undetected because monitoring and enforcement are selective. Finally, even when a firm is audited and found in violation, or has an accident, the firm may be able through litigation to avoid noncompliance sanctions or liabilities. Each of these cases may be viewed as the result of an information imperfection, either in monitoring or enforcement. The result of such imperfections, rationally anticipated by the firm and the regulator, can be modeled in the form of various games under incomplete information. ${ }^{21}$ However, although the nature and quality of information is central to achieving efficient regulation in these models, this line of research does not speak to the focus of this paper on informational regulation.

Of more direct concern to this paper are the consequences for firm behavior of the monitoring and enforcement incentives resulting from information provided to third parties, whether they are local communities, non-governmental organizations (NGOs), or consumers. In this area, we can identify three major streams of related economic research. The first is the approach of internalizing externalities through property rights which is identified with Ronald 
Coase. The second is transactions cost economics, associated with Oliver Williamson, which is of importance in understanding regulatory compliance costs. The third approach is represented by Gary Becker's analysis of interest group dynamics, which includes the impact of interest group dynamics on self-regulation by industry to ward off anticipated establishment of more stringent standards induced by pressure group activities.

\subsection{Information and Coasean Bargaining}

Ronald Coase ${ }^{(10)}$ argued that one way of approaching externalities such as environmental damages is to clarify the property rights involved and then let the parties negotiate appropriate terms. For example, if a firm owns the right to emit a certain amount per year of a given pollutant, then surrounding communities who may suffer damages from the pollutant would, under this approach, bargain with the firm to emit less of the pollutant. They would, in effect, pay the firm to reduce its pollution if their damages were higher than the cost of pollution reduction. In the famous "Coase Theorem" it is demonstrated that, in the absence of transactions costs and with complete information, the resulting bargaining outcome will be Pareto efficient. However, the Coasean assumptions necessary for efficiency are rarely satisfied ${ }^{(17)}$. Identifying pollution sources and owners and then bargaining with them is fraught with transactions costs and informational asymmetries.

Because of these problems, few argue for the widespread application of a pure Coasean approach. But one interpretation of the move toward IR would be simply to reduce the transactions costs of identifying pollution sources, thus making it less expensive to bargain effectively with agents controlling these sources about appropriate levels of risk and environmental impacts. This interpretation is especially compelling when one considers impacts which are largely local and 
borne by an identified group of stakeholders, such as a community hosting an industrial facility. ${ }^{22 a}$

For example, with respect to a local printing shop or a bakery, it is useful to frame the economic problem in terms of two actors: the "company" and the "community." The bargaining problem of interest might be the level of output $\mathrm{Q}$ and the level of pollution (or risk) $\mathrm{Z}$ of the company. ${ }^{22}$ The company and the community might have very different valuations of the appropriate levels of $\mathrm{Q}$ and $\mathrm{Z}$. One can imagine a number of scenarios resulting from this situation.

In one scenario, the company would be left entirely to its own discretion to choose $\mathrm{Q}$ and $\mathrm{Z}$, possibly facing local pressure to reduce $Z$. But in the absence of information, and possibly with the burden of proof on the community, large transactions costs would provide significant barriers to the community to undertake effective pressure. In a second scenario, the company could be required to provide verified information on its output $Q$ and level of pollution $Z$, decreasing the transactions costs of undertaking pressure. In addition, the company might also be required to show that $Z$ was below some regulatory standard $Z^{*}(Q)$.

One can complicate the above scenarios and the respective bargaining problem in various ways. For example, the information that the company is required to publish might be only imperfectly related to community preferences or it might be insufficient to allow the community to evaluate precisely the actual or expected damages caused by the company. This is claimed by 
many to be the case with eco-labels and with worst case scenarios. ${ }^{23}$ As another complication, consider activities by the local community (such as emergency response) which may interact with company decisions in reducing risk or enhancing welfare. ${ }^{24}$

Even with these complications, the basic point remains. Improved information and reduced transactions costs will approximate the Coasean ideal. This approach works well only if the information required to be revealed by the company can be cheaply verified and is aligned with the community's values. If the information is not informative or meaningful to the community, then improving it does little to improve the efficiency of their "bargaining process" with the company. Similarly, if the company is required (either explicitly or implicitly through community pressure comparing the company to other companies) to comply with a uniform standard $Z^{*}$ which is not efficient, then the ease of monitoring and enforcing a legal but inefficient standard will not produce socially efficient results. In particular, if there are many companies in the community responsible for an overall level of pollution or risk, the usual transactions costs and free-rider problems of the Coasean solution reemerge.

\subsection{Transactions Costs and Compliance Costs}

The traditional economic view of regulation was not much concerned with inefficiencies and costs introduced by the regulatory process itself. Williamson ${ }^{(65)(66)}$ rectified this oversight by arguing that, especially in noncompetitive settings, an analysis of the "governance structure" mediating transactions required attention to the costs of governance itself. The regulatory setting is rife with potential for transactions costs, and there is a growing literature on regulatory transactions 
costs. $^{25}$ This framework is of special interest in the area of environmental regulation, although no direct application of Williamson's work appears as yet to have been undertaken. Indeed, much of the recent political debate on compliance costs and market-based approaches to environmental regulation is focused on the poor cost-effectiveness of the current regulations caused by high regulatory transactions costs.

Although we know of no research on the issue, IR has the potential for reducing regulatory transactions costs in both monitoring and enforcement. On the monitoring side, the use of third parties, certified by state or federal regulators, together with an informed public (or public surrogates such as NGOs) has the potential for increasing the efficiency and service quality of monitoring and inspection services as compared with the more bureaucratic procedures within government. The link of third-party and public monitoring approaches with IR is the enhancement of public and community trust in the regulatory process through open access to the results of this activity. Absent $\mathbb{R}$, the public may believe that the burden of monitoring and enforcement has been off-loaded to an ineffective, rubber-stamping, third-party service organization that is captured by the regulated industry. Note that even with $\mathbb{R}$, oversight by regulators must continue to ensure the credibility of the information released to the public. In many cases, however, one would expect significant reductions in the level of regulatory monitoring costs under $\mathbb{R}$. The availability on a broad scale of standardized data on company operations could also be of value in diagnosing common factors leading to accidents or incidents. ${ }^{26}$

A key question on the effectiveness of $\mathbb{R}$ and third-party monitoring is not simply the reduction in regulatory transactions costs but the extent of ancillary benefits from the third-party activity (e.g., economies of scope between discovery of problems and repair of problems, better measurement and quality systems resulting from third-party services, and other technical support 
and advice resulting from the third-party activity which might improve company operations beyond simple assurance of regulatory compliance). On the community side, a key question is the extent to which IR reduces "dread risk" before the fact ${ }^{(59)}$ and promotes efficiency in response after the fact. A further question is whether the information released to the public as part of IR is understood by the public, that is, whether it is sufficient for the public to form a meaningful impression of the risk and environmental impact of specific company operations.

With respect to enforcement and regulatory learning, a similar case can be made for the potential benefits of IR in reducing transactions costs. Relying on market pressures, torts law (see section 4 below) and public pressure to enforce environmental standards replaces regulators with thousands of unpaid, proactive enforcers in society. ${ }^{27}$ The essential ingredient for effectiveness of this scenario is reliable information about the company's operations.

\subsection{Interest Groups and Political Economics of Regulation}

Gary Becker's work on interest groups (1983) reinvigorated a theme which has long been understood as a driving force of government policy and regulation, namely, public interest groups. In Becker's analysis, such groups are represented as influencing public policy with an effectiveness that varies by the type of group, the size of the group, and the effort expended by group members. Such effort enjoys an anticipated return based on influence in the form of subsidies or reduced taxes for group members. The equilibrium of the resulting game between pressure groups can be understood to capture the political economic balance of interest group efforts to influence public policy in directions which will advantage each respective group.

Building on this theory, Maxwell, Lyon and Hacket ${ }^{(45)}(\mathrm{MLH})$ have proposed an interesting model of interest group influences on environmental regulation and industry reactions. They 
consider an industry which can elect to self-regulate its pollution abatement standards or to be confronted by possibly stricter regulations imposed by the government. They model the resulting choice problem as a three-stage game. In the first stage, symmetric firms voluntarily choose a level of abatement. In the second stage, identical consumers (who receive utility from the good produced by the industry but disutility from the industry's pollution) observe the level of abatement chosen and decide whether or not to organize themselves in order to influence the government to enact regulations limiting the industry's pollution. If they do organize (and this is not costless) to exert influence, then the industry and the public play an "influence game" of the type described by Becker to determine the regulatory standard to be imposed on industry. At the outcome of this influence game, in the third stage, industry complies with the regulation (if any), and companies play a Cournot game to determine outputs and profits.

Of interest here is the addition of a voluntary stage of compliance which is the result of the anticipated outcome of an influence game. While $\mathbb{R}$ is not the focus of the MLH model, and perfect knowledge on the level of industry pollution is assumed for citizens, the MLH model nonetheless provides a reasonable account of the central role of an informed public in IR. It also captures, in the spirit of Stigler ${ }^{(62)}$, Olson ${ }^{(47)}$, and Peltzman ${ }^{(52)}$, the costly nature of organizing to exert influence. Indeed, it is tempting to interpret the effects of IR as decreasing the transactions costs of organizing an interest group and increasing its effectiveness. ${ }^{28}$ Paradoxically, such reductions in transactions costs are not necessarily welfare improving for the MLH model because this model makes it less desirable for the industry to preempt regulation with self-regulation, with the consequence that industry will await the more costly outcome of the influence game which (if organizing costs are low enough) it knows will be played. Such welfare results would change if the MLH framework were extended to accommodate the impact of IR in reducing information 
imperfections, with consequent benefits of a more accurate determination by the public of the costs of playing the influence game.

Summarizing informational aspects of regulatory economics, we see some interesting points of connection to $\mathbb{R}$, but little direct empirical or theoretical work. To date, the economics literature has been concerned with a postulated official regulator, usually a selfless public surrogate. Thirdparty issues and the public as regulator have been much less prominent themes. Nonetheless, we can see a number of ties to the economics literature, from Coase onward. The most intuitively appealing consequence of $I R$ is its potential to reduce monitoring and enforcement transactions costs of regulation. More important, however, may be the effects of $\mathbb{R}$ on the political economic forces shaping environmental regulation. Perhaps because the usual starting point of economic analysis is perfect information, $\mathbb{R}$ remains largely unexplored ternitory.

\section{Informational Regulation in Environmental Law}

We now consider $\mathbb{R}$ from a legal perspective. There are two basic conventional approaches to environmental regulation. The first and most ancient focuses on the use of a legal system to define and allow for the enforcement of property rights. Given the focus on private rights and private enforcement for transgressions of them, we call this a "private rights" approach. A second and more recent form of regulation relies on governmental statutes and enforcement of specification-based or performance-based standards set by regulation. Because enforcement of these statutes is usually the responsibility of the government, we call this a "government-centered" approach. Neither of these conventional approaches fully captures the flexibility available in approaches that employ informational methods. We argue for a third approach of "informational regulation." The primary social institutions employed by $I R$ methods are economic markets and 
public opinion.

\subsection{Private Rights Regulation}

Private rights regulation takes as its focus the legally recognized rights of an individual entity, whether a natural human being or an organization (typically a business firm), and the enforcement of these rights against infringement by others. Solutions to environmental problems are hammered out through interpersonal transactions, including contracts, sales of property, and resolutions of disputes about them (either through litigation or alternative methods). Legal institutions support private rights regulation by enforcing contracts and ownership rights to property. But legal institutions, primarily courts, become involved directly only when disputes arise. Even then, the focus of the courts is limited to determining the legally cognizable interests of the persons involved in a dispute and determining who is "right" in each particular case. Government, acting either through legislation or adjudication, is limited to setting the rules of the game by which legal persons deal with one another and enforce the rules against each other in cases of conflict.

Because an incident of property ownership includes an important environmental component, including protection of the right to enjoy the benefits of land, private property rights have long provided an important vehicle for environmental regulation. Nuisance law provides the classical form of this environmental regulation. ${ }^{29}$ If one property owner is harmed by environmental damage caused by another, an action may be brought asserting intentional harm, negligence, or occasionally strict liability, depending on the nature of the harm ${ }^{(54)}$.

A more recent variant of this approach to environmental regulation creates new private property rights to bring within the property system parts of the natural environment traditionally left 
outside of the system. A good example is the proposal to extend private rights of ownership to endangered species ${ }^{(26)}$. The reasoning is that extending private ownership to parts of the natural environment that bear the brunt of externalities enables the market better to value the price of these harms. In economic terms, the environmental costs are internalized.

Because both the traditional private rights approach to environmental regulation and its more recent variants rely on individual legal persons who are property owners to hold and enforce property rights against those who may infringe them, they may also be accurately described in economic terms as Coasean or neo-Coasean ${ }^{(10,49)}$. A traditional Coasean approach is simply to recognize and enforce property rights as they have developed historically. Over time, as property owners bring disputes to courts, a common law develops to define the nature of property rights and the boundaries of nuisance and, conversely, the power to use one's property to impose noncompensable or non-remediable harms on others. ${ }^{30}$ In addition, statutory law influences the development of property rights -- though the allowable parameters of statutory change may include constitutional limitations, such as a prohibition against "takings" of private property without just compensation. $^{31}$ A neo-Coasean approach uses the same method of property rights definition and enforcement by property owners, but it extends property rights to additional natural resources that had previously been outside of the legal universe of private property (e.g., endangered species).

With respect to environmental specification-based and performance-based standards, a private rights approach, whether Coasean or neo-Coasean, usually develops standards on an ad hoc basis through adjudication. In common law countries, the development of the law of torts occurs largely through judicial precedent. Alternatively, statutes and custom may supply standards of applicable law. A virtue of the private rights approach is the decentralized definition and application of standards in individualized disputes. This allows for variety and flexibility in 
fashioning different standards for particular problem contexts. At the same time, a private rights approach cannot easily create uniform legal standards, which are desirable when a particular problem context involves very large numbers of actors and addressing the problem in an effective manner requires societal coordination ${ }^{(27)}$.

Enforcement of private rights is decentralized. Because much of law is a matter of dispute resolution, the role of information is limited to the purposes of individual lawsuits. Legal rules compel "discovery" of various kinds of information in the event of a dispute. However, the information is not necessarily made public or widely available. In private rights regulation, information is limited to its relevance in a specific dispute. ${ }^{32}$

\subsection{Government-centered Regulation}

A second approach to environmental regulation has developed in recognition of problems that arise when an approach emphasizing only the enforcement of private rights is followed. The "tragedy of the commons" identifies severe limitations of a decentralized, individualized private rights system ${ }^{(23,55)}$. These problems arise when, in the absence of a collectively organized authority, individuals act rationally from their own narrow perspectives, but irrationally from the point of view of the society as a whole. Examples include overpopulation, overfishing, regional air and water pollution, and global climate change.

The usual alternative source of regulation for commons problems is to look to the government ${ }^{(8,28)}$. Government-centered regulation focuses on the enforcement of mandated standards on legal persons (including firms as well as people). In economic terms, the governmentcentered approach sees environmental externalities to exhibit market failure. The traditional allocation of private rights is found to be incapable of dealing effectively with certain wider 
environmental problems. The solution is for government to set performance or specification standards directly.

The conventional government-centered approach is to enact into law -- either through statutes or through regulations adopted by an authorized environmental agency (in the United States, the EPA or its state equivalent) -- performance or specification standards which businesses must follow. Usually, the choice of standards is hierarchical in a government-centered approach. Although regulated entities may influence the details of the standards through lobbying, negotiated rulemaking, or legal challenges to specific standards, the primary authority for defining standards remains with the government.

Enforcement is also government-centered, usually involving an investigation and civil or criminal legal action brought by an administrative agency against violators of the standards. An alternative is to delegate authority to individual citizens to enforce government standards as "private attorneys general." ${ }^{33}$

\subsection{An Alternative Model of Informational Regulation}

Informational regulation may be used in conjunction with both government-centered and private rights approaches. The mandated disclosure of environmental information about compliance is one way to enforce governmental performance and specification standards. In some cases, adding $\mathbb{R}$ to a government-centered regulation may improve the overall efficiency of the regulation. In other cases, the added cost of $\mathbb{R}$ may outweigh the efficiency gains in enforcement. In private rights regulation, $\mathbb{R}$ may improve the bargaining position of various groups in society who have an interest in the level of environmental performance of business firms (see section 3 above). IR may also involve ex ante disclosure of information about potentially harmful events, 
such as those that result in lawsuits for "toxic torts." IR would decrease the transactions costs of future plaintiffs and increase the incentives for firms to avoid harmful incidents.

However, neither government-centered nor private rights regulation employs information as a central object of regulation. IR in its pure form opens up another possibility. IR is an option that focuses on the effect that disclosure of information has on the social institutions of markets and public opinion. Whether this kind of an informational approach makes sense will depend on the specific problem context involved, as well as an assessment of the relative merits of what kind of standards should be used, how they should be defined, and how they should be enforced. This process of making this determination is the subject of Section 5. Our purpose in this section is first to describe this different approach.

Some environmental problems may recommend IR as the best way to encourage the production and disclosure of information about an environmental issue. Relatively recently discovered problems, for example, may not permit wise policy choices to be made about adopting exact rights or standards, and in these cases the regulatory response may do better to encourage understanding the problem, and experimenting with alternative approaches to dealing with it, before a "solution" is adopted. If a regulatory solution is imposed before a problem is very well understood, it is often not likely to work and may even do considerable harm at great expense. Other problems may require better communication and education about the problem among various social groups and interests who are affected by it. IR may improve social decision making in these circumstances, leaving the substantive results to an enhanced communicative process.

With respect to performance or specification standards, IR may allow for alternative sources of standards. An $\mathbb{R}$ approach may recommend that some standards derive from professional organizations or evolve in terms of "best practice" standards within business groups. The mere 
requirement of disclosure of information may achieve this result through the operation of behavioral norms, as well as through economic processes. Some governmental supervision of organizational standard-making may be needed, but $\mathbb{R}$ may encourage mid-level social institutions to create, criticize, and revise their own environmental standards for certain kinds of problems.

With respect to enforcement, $\mathbb{R}$ would rely heavily on markets and public opinion. Although in some cases government may also mandate the need to produce and disclose information, enforcement of standards would be expected to occur through the combined pressure of economic markets and public opinion to live up to evolving standards.

IR does not directly impose standards. It focuses instead on structuring information and communications among interest groups in society. In this sense, it aims at a middle-level of institutions and the interactions among social groups, rather than the commanding heights of government. IR is also not concerned directly with the allocation of private rights to legal persons. Instead, it attempts to structure institutional and collective decision making through channeling the flow of particular kinds of information. IR therefore relies for its effectiveness on intermediary social structures, such as markets, broad-based voluntary associations, and public opinion, rather than government diktat.

For example, consider the generic problem of siting a facility with some degree of environmental risk. A private rights approach would look only to the prevailing property and torts rights of neighbors and the extent to which they could enforce these rights against the proposed "nuisance." Both sides would look to prevailing common law rules, a legal prediction of the likelihood of victory, and the expected litigation costs as compared to the potential harm to be averted or gain to be recognized. Alternatively, both sides could look to a possible governmentcentered solution. Zoning laws, for example, could be invoked or changed, depending on one's 
point of view. Or some sort of government-mandated risk assessment might be required. In the end, one worries that too often the most likely result for either alternative is that the side with the most legal or political clout wins.

An informational approach might instead try to ameliorate the conflict by increasing the amount of reliable knowledge about the proposed facility and its attendant risks. Certification reports or disclosure of risk assessments might be distributed to improve understanding and reduce the gap separating the various interests involved ${ }^{(36)}$. $\mathbb{R}$ may in this circumstance provide for specific governmental assurances to lessen irrational fears and mistrust among various groups. Improved information about specific issues may increase the chances of a negotiated solution. Even in the absence of successful negotiation, effective IR may lessen the distance between competing versions of disputed facts, including: the level of risk involved, the quantitative comparisons of the level of risk imposed by similar facilities in other communities, the need for a particular kind of facility from a broad social perspective, and the fairness of procedures followed in the specific siting.

This is only a sketch of one example of how IR might work. The main point is that IR aims to resolve environmental issues through regulatory processes that assure or encourage the production and dissemination of accurate, reliable, and relevant information. It would not dictate substantive results through governmental standards or grant private rights as trumps.

To summarize, we have identified three models of regulation from the point of view of the importance of information. First, a private rights approach focuses on defining interests and resolving conflicts among individuals. This approach develops information about environmental problems only in the crucible of litigation (or potential litigation) over conflicting property or contract rights and in actions alleging tortious harm. Second, a government-centered approach 
focuses on legally mandated performance standards or specifications. The government may require the disclosure of information to increase the effectiveness of enforcing its standards and specifications. Or it may produce information on its own about violations through investigation and litigation. Third, we identify an intermediate form of informational regulation. Rather than private litigation or the government, IR in its pure form relies on mid-level institutions such as the market and public opinion. It attempts to improve social incentives through the production of accurate and widely available informations, without the direct threat of increased litigation or direct government regulation (see Figure 3). ${ }^{39}$

[Figure 3 about here]

\section{Assessing the Effectiveness of Informational Regulation}

There is a rich literature on cost-benefit approaches to regulation in general and risk regulation in particular ${ }^{34}$. These approaches apply various efficiency and equity criteria in evaluating alternative regulatory approaches. For our purposes, the following classification of evaluative criteria is useful.

5.1. Static efficiency and effectiveness. Allocative efficiency (including scale and scope efficiency), ${ }^{35} \mathrm{X}$-efficiency, ${ }^{36}$ and transactions costs efficiency ${ }^{37}$ are traditional evaluative measures applied to regulations and regulatory institutions. Together with cost and risk effectiveness measures of a regulation in accomplishing its intended purpose, these measures are the standards against which alternative regulatory approaches are judged, for example, during the coordinated oversight by the Office of Management and Budget and the Office of the Vice President of all major federal regulations ${ }^{38}$. 
5.2. Dynamic efficiency and learning. A second category of efficiency measures the impact of regulation on technological progress, innovation, and learning. Such measures have usually not been at the forefront of regulatory cost-benefit studies because of measurement difficulties, but they are clearly important. Although the impact of regulation on innovation has been predominantly found to be negative ${ }^{(11)}$, patents and the regulation of intellectual property rights are examples of innovation-enhancing regulation. Similarly, establishing standards can provide a boost to market innovation by providing a clear target against which to measure technologies designed to meet the given standard. An important and distinguishing feature of dynamic efficiency in the environmental context is the reversibility of decisions related to the environment. To the extent that decisions entail irreversible impacts, and especially if these are potentially catastrophic or intergenerational, they may imply significant difficulties with the traditional applied welfare calculus for evaluation.

One of IR's strengths relative to other forms of regulation is the public nature of information implied by $\mathbb{R}$. Over time, this has the potential to promote defensible diagnostic, scientific, and engineering studies of specific risks, as well as learning about both the risk itself and the technological and managerial factors influencing the risk.

5.3. Empirical and systemic legitimacy. A third class of criteria relates to whether the regulation is viewed as being legitimate by the public, and whether it further enjoys normative characteristics such as being transparent, understandable, the result of an open and democratic process, and so forth. We refer to the former type, acceptability to the public, as "empirical legitimacy," and the latter type as "systemic legitimacy" ${ }^{(4,48)} .{ }^{39}$ Empirical legitimacy may be determined by such complex factors as the perception of the regulation's equity, credibility, accountability for results, effectiveness, and even efficiency. Systemic legitimacy is determined by 
the normative principles underlying the fabric of law and politics. ${ }^{40}$

While a complete discussion is beyond the scope of this paper, the above criteria provide a starting point for prescriptive theory in evaluating and choosing among alternative regulatory approaches to a given class of environmental problems. Note, in particular, that the problem context itself will imply different regulatory outcomes. For some problems, such as preventing slips and falls in the workplace, there may be only limited potential for technological innovation so that the emphasis in regulating this risk should be on static efficiency. In other cases, such as the consequences for worker health and safety of new chemicals or processes, the problem itself may be poorly understood so that learning and experimentation are important aspects of choosing a regulation. In still other cases, for example, global climate change, the catastrophic and intergenerational risks associated with a problem may dominate the choice of regulation.

A prescriptive theory of regulatory design would balance the above three general criteria (static efficiency, dynamic efficiency, and legitimacy) in choosing a regulatory approach to a particular environmental risk. Problems with features implying significant net benefits from increasing one or another of the efficiency or legitimacy measures should (or descriptively will) tend toward regulations emphasizing these measures. (See Figure 4). Under this multi-criteria approach to evaluating regulatory options, a balanced scorecard across criteria is the objective.

[Figure 4 about here]

\section{Concluding Remarks}

The above discussion suggests the essential factors influencing whether $\mathrm{IR}$ is appropriate. First, as noted in section 3, transactions costs (under static efficiency) may be a prime mover -- as 
they are under Section 112(r) of the Clean Air Act Amendments, where the use of third parties for monitoring and enforcement of the development of RMPs is necessary given the roughly 140,000 sites/facilities to which Section 112(r) applies ${ }^{(16)}$. Similarly, the communication of worst case scenarios and other relevant information to community emergency response organizations, which is also stipulated in Section 112(r), is intuitively compelling. These organizations can properly plan emergency response activities when industrial risks may entail significant off-site consequences ${ }^{(56)}$. Finally, $\mathbb{R}$ is important in giving surrounding communities a sense of control and security when information and communication are absent or distrusted.

However important these local informational activities may be, the broader issues raised by IR for diagnostic and national monitoring activity and for influencing the political agenda may be even more important. As we know from principal-agent theory, a foundation for effectiveness of $\mathbb{R}$ is that the information resulting from it must be actually informative in the sense that the IRbased information revealed to the public should correspond to actual improvements in company operations. One informative signal is compliance with performance and specification standards. For such signals, IR would play the role of reinforcing monitoring and enforcement. In areas like eco-labels and the developing international ISO 14000 standards, however, we see a slightly different logic developing. These initiatives proceed beyond traditional reliance on the regulatory bureaucracy and replace centrally defined performance and specification standards with internally defined but externally monitored signals of environmental quality and prudent risk management. It is an open question whether this expanded scope of IR will be beneficial and whether eco-labels and ISO 14000 certifications will indeed prove to be informative signals on company operations which can be generated and verified at reasonable cost.

In the area of major accident prevention and emergency response, it seems clear that IR, as 
foreseen in Section 112(r), has an important role to play. It remains to be seen in which other areas of environmental regulation the basic idea of IR will yield significant improvements in perceived benefits in reducing actual and perceived risks. 


\section{References}

1. Anderson, Terry L. and Donald R. Leal. 1991. Free Market Environmentalism. Pacific Research Institute for Public Policy: San Francisco.

2. Baram, Michael S. 1994. "Multinational Corporations, Private Codes, and Technology Transfer for Sustainable Development," 24 Environmental Law Reporter 33-65.

3. Becker, Gary S. 1983. "A Theory of Competition among PressureGroups for Political Influence." XCVIII Quarterly Journal of Economics 371-400.

4. Beetham, David. 1991. The Legitimation of Power. Humanities Press International: Atlantic Highlands, N.J.

5. Bobertz, Bradley G. 1995. "Legitimizing Pollution Through Scapegoating Theory." 73 Texas Law Review 711-51.

6. Boyer, Barry and Errol Meidinger. 1985. "Privatizing Regulatory Enforcement: A Preliminary Assessment of Citizen Suits under Federal Environmental Laws." 34 Buffalo Law Review 833-964.

7. Breyer, Stephen. 1993. Breaking the Vicious Circle: Toward Effective Risk Regulation. Harvard University Press: Cambridge.

8. Burtraw, Dallas and Paul R. Portney. 1991. "Environmental Policy in the United States" in Economic Policy Towards the Environment. Dieter Helm ed. Graham \& Trotman/Martinus Nijhoff: London, Dortrecht, Boston.

9. Chinander, Karen R., Paul R. Kleindorfer and Howard C. Kunreuther. 1995. "Performancebased Regulation of Chemical Accident Risks," Paper presented at the Wharton Impact Conference on Market-Based Innovations to Regulating Chemical Accident Risks, University of Pennsylvania, October 13-14, 1995. 
10. Coase, Ronald H. 1960. "The Problem of Social Cost," 3 Journal of Law and Economics 1-44.

11. Crew, Michael A. and Paul R. Kleindorfer. 1986. The Economics of Public Utility Regulation. MIT Press: Cambridge.

12. Dasgupta, P., P. Hammond and E. Maskin. 1980. "On Imperfect Information and Optimal Pollution Control." 47 Review of Economic Studies 857-860.

13. Ellicteson, Robert C. 1991. Order without Law: How Neighbors Settle Disputes. Harvard University Press: Cambridge, Mass.

14. Environmental Protection Agency. August, 1994. "Using Information Strategically to Protect Human Health and the Environment." EPA 270-K-94-002. Environmental Information and Assessment Committee; National Advisory Council for Environmental Policy and Technology.

15. Epstein, Richard A. 1985. Takings: Private Property and thePower of Eminent Domain. Harvard University Press: Cambridge, Mass.

16. Er. Jweeping, Howard Kunreuther \& Isadore Rosenthal. 1996."The Use of Third Parties in Implementing EPA's Proposed Rule on Risk Management Programs for Chemical Accidental Risk Prevention." Working Paper, Wharton Risk Management and Decision Processes Center, University of Pennsylvania.

17. Gruenspecht, Howard K. and Lester B. Lave. 1989. "The Economicsof Health, Safety and Environmental Regulation." Chapter 26 in Richard Schmalensee and Robert D. Willig (eds.), Handbook of Industrial Organization, Vol. II, North Holland: Amsterdam.

18. Haar, Charles M. and Michael Allan Wolf. 1989. Land-Use Planning: A Casebook on the Use, Misuse, and Re-use of Urban Land. 4th ed. Little, Brown: Boston.

19. Habermas, Jürgen 1975. Legitimation Crisis. Trans. Thomas McCarthy. Beacon Press: Boston. 
20. Habermas, Jürgen . 1984. The Theory of Communicative Action: Reason and the Rationalization of Society. Vol. 1. Trans. Thomas McCarthy. Beacon Press: Boston.

21. Habermas, Jürgen 1992. Faktizität und Geltung: Beiträge zur Diskurstheorie des Rechts und des demokratishchen Rechtstaats. Frankfurt am Main: Suhrkamp.

22. Hahn, Robert W. and Robert N. Stavins. 1991. "Incentive-Based Environmental Regulation: A New Era from an Old Idea?" 18 Ecology Law Quarterly 1-42.

23. Hardin, Garrett. 1968. "The Tragedy of the Commons," 162 Science 1243-48.

24. Harr, Jonathan. 1995. A Civil Action. Random House, New York

25. Harter, Philip J. 1982. "Negotiated Regulations: A Cure for Malaise," 71 Georgetown Law Journal: $1-113$.

26. Heimert, Andrew J. 1995. Note. "How the Elephant Lost His Tusks," 104 Yale Law Journal 1473-1506.

27. Helm, Dieter and David Pearce. 1991. "Economic Policy Towards the Environment: An Overview" in Economic Policy Toward the Environment 1-24. Dieter Helm ed. Graham \& Trotman/Martinus Nijhoff: London, Dortrecht, Boston.

28. Johnson, Stanley P. and Guy Corcelle. 1989. The Environmental Policy of the European Communities. Stanley P. Johnson ed. Graham \& Trotman/Martinus Nijhoff: London, Dortrecht, Boston.

29. Jorde, Thomas M. and David J. Teece. 1992. Antitrust, Innovation and Competitiveness. Oxford University Press: New York.

30. June, Robert B. 1994. "Citizens Suits: The Structure of Standing Requirements for Citizen Suits and the Scope of Congressional Power." 24 Environmental Law 761-99

31. Kambhu, J. 1989. "Regulatory Standards, Noncompliance and Enforcement," 1 Journal of 
Regulatory Economics 103-114.

32. Kaplow, Louis. 1992. "Rules versus Standards: An Economic Analysis." 42 Duke Law Journal 557-629.

33. Kim, Ki Joong. 1993. "Three Essays on Current Issues of Regulatory Economics." Ph.D. Dissertation, Department of Economics, University of Pennsylvania.

34. Klein, William A. 1982. “The Modern Business Organization: Bargaining Under Constraints”. 91 Yale Law Joumal 1521-64.

35. Kleindorfer, Paul R. and Howard C. Kunreuther (eds.). 1987. Insuring and Managing Hazardous Risks, Springer Verlag: Berlin.

36. Kleindorfer, Paul R. and Howard C. Kunreuther. 1994. "Siting of Hazardous Facilities." In Pollack, S. and M. Rothkopf, Handbook of Operations Research in the Public Sector, Elsevier: New York.

37. Kleindorfer, Paul R., Howard C. Kunreuther and Paul Schoemaker. 1993. Decision Sciences. Cambridge University Press: Cambridge.

38. Krier, James E. 1971. "The Pollution Problem and Legal Institutions: A Conceptual Overview," 18 UCLA Law Review 429-77.

39. Krier, James E. 1992. "The Tragedy of the Commons, Part Two," 15 Harvard Journal of Law and Public Policy 325-47.

40. Ladeur, Karl-Heinz. 1995. Das Umweltrecht der Wissensgesellschaft. Duncker \& Humbolt: Berlin.

41. Leibenstein, Harvey. 1966. "Allocative Efficiency versus X-Efficiency", 56 American Economic Review 392-415.

42. Loss, Louis. 1988. Fundamentals of Securities Regulation. 2nd edition. Little, Brown: 
Boston and Toronto.

43. Luken, Ralph A. 1990. Efficiency in Environmental Regulation. Kluwer Academic Publishers: Boston.

44. Lyndon, Mary L. 1989. “ Information Economics and Chemical Toxicity: Designing Laws to Produce and Use Data" 87 Michigan Law Review 1795-1861.

45. Maxwell, John, Thomas Lyon and Steven Hackett. April 1995. "Self-Regulation and Social Welfare: A Model of Corporate Environmentalism", Working Paper, Graduate School of Business, Indiana University, April, 1995.

46. Menell, Peter S. 1995. “ Structuring a Market-Oriented Federal Eco-Information Policy” 54 Maryland Law Review 1435-74

47. Olson, Mancur. 1971. The Logic of Collective Action: Public Goods and the Theory of Groups. Cambridge: Harvard University Press.

48. Orts, Eric W. 1993. "Positive Law and Systemic Legitimacy," 6 Ratio Juris 245-78.

49. ----. 1995a. "Reflexive Environmental Law," 89 Northwestern University Law Review 12271340.

50. -.... 1995b. "A Reflexive Model of Environmental Law," 5 Journal of Business Ethics 779-94

51. ----. 1995c. "The Legitimacy of Multinational Corporations," in Progressive Corporate Law (Lawrence E. Mitchell ed.). Westview Press

52. Peltzman, Sam. 1976. "Toward a More General Theory of Regulation." 19 Journal of Law and Regulation 211-248.

53. Pollak, Robert A. March 1995. "Regulating Risks", 33 Journal of $\quad$ Economic Literature 171-91.

54. Rodgers, William H. 1986. Environmental Law: Air and Water Pollution. Vol 1. West 
Publishing Co: St. Paul.

55. Rose, Carol M. 1991. "Rethinking Environmental Controls: Management Strategies for Common Resources," 1991 Duke Law Journal 1-38.

56. Rosenthal, Isadore, Patrick J. McNulty and Lyse Helsing. 1996. "The Role of the Community and Risk Communication in the Implementation of EPA's Proposed Rule on Risk Management Programs for Chemical Accident Release Prevention." Working Paper, Wharton Risk Management and Decision Processes Center, University of Pennsylvania.

57. Shane, Peter M. 1995. "Political Accountability in a System of Checks and Balances: The Case of Presidential Review of Rulemaking" 48 Arkansas Law Review 161-214.

58. Shavell, Steven. 1984. "A Model of the Optimal Use of Liability and Safety Regulation." 15 RAND Journal of Economics 271-280.

59. Slovic, Paul, "Informing and Educating the Public about Risk", in Kleindorfer and Kunreuther (1987), Chapter 10, pp. 307-333.

60. Smith, J. Andy, III. 1993. "The CERES Principles: A Voluntary Code for Corporate Environmental Responsibility," 18 Yale Journal of International Law 307-17.

61. Spindler, Gerald, "Umweltschutz durch private Prhfungen von Unternehmensorganisationen: Die EG-_ko-Audit-VO", Working Paper, Faculty of Law, University of Frankfurt, 1995.

62. Stigler, George. 1971. "The Theory of Economic Regulation." 2 Bell Journal of Economics and Management Science 3-21.

63. Sunstein, Cass R. 1992. “What's Standing After-Lujan? Of Citizen Suits, 'Inquires', and Article III." 91 Michigan Law Review 163-236

64. Tirole, Jean. 1988. The Theory of Industrial Organization, MIT Press: Cambridge.

65. Williamson, Oliver E. 1979. "Transactions Cost Economics: the Governance of Contractual 
Relations." 22 Journal of Law and Economics 233-61:

66. -..-. 1984. "The Economics of Governance: Framework and Implications." 140 Journal of Institutional and Theoretical Economics 195-223. 


\section{Endnotes}

The authors thank Michael Baram, Jason Johnston, Howard Kunreuther and Irv Rosenthal for comments on an earlier draft of this paper.

- Universal Furniture Professor of Decision Sciences and Economics and Professor of Public Policy and Management, The Wharton School, University of Pennsylvania.

** Associate Professor of Legal Studies, The Wharton School, University of Pennsylvania.

${ }^{1}$ The Emergency Planning and Community Right-to-Know Act (EPCRA) requires the Environmental Protection Agency (EPA) to maintain a national toxic release inventory (TRI) on a computer database that is available to the public. Businesses that use specific toxic chemicals in manufacturing or other processes must annually file a toxic release chemical form with the EPA, describing the general use of the chemicals, estimating the amount of the chemical on site, specifying waste treatment or disposal methods, and reporting on the annual amount of the chemicals released into the environment. This information is then made available through the computerized TRI system. 42 U.S.C. 11023 (1996); 40 C.F.R. $§ 302.8$ (1996).

${ }^{2}$ A prominent example is the European Union's eco-label. See Council Regulation 880/92 of 23 March 1992 on a Community Eco-label Award Scheme, 1992 O.J. (L 99) 1. For an overview of the current law of environmental marketing regulation, including environmental labels, see Orts ${ }^{(49)}$.

342 U.S.C. $\S 7412(r)$. See Final Rule, List of Regulated Substances and Thresholds for Accidental Release Prevention; Requirements for Petitions Under Section 112(r) of the Clear Air Act as Amended, 59 Fed. Reg. 4478 (Jan. 31, 1994); Risk Management Programs for Chemical Accidental Release Prevention, 58 Fed. Reg. 54190 (to be codified at 40 C.F.R. pt. 86) (rule proposed Oct. 20, 1993). For further description and assessment, see ${ }^{(16,56)}$.

${ }^{4} 42$ U.S.C. $\S 300$ g-3 (c) (4) (1996)

${ }^{5}$ Self-certification of compliance with the ISO 14000 standards is also possible. For details on this developing set of standards and its possible role in environmental regulation, see Dray and Foster (1996).

${ }^{6}$ After this article was written, the EPA announced an ambitious proposal to extend what we call information regulation to include the public dissemination of a significantly increased amount of data about the environmental performance of a great number of facilities. These data include information about permit violations, toxic releases, and demographics of neighborhoods. See John H. Cushman, Jr., EPA is Pressing Plan to Publicize Pollution Data, N.Y. Times, August 12, 1997 , at A1. Time does not allow us to provide an analysis of this important development, but it corresponds with the general tendency we observe toward IR. 
${ }^{7}$ A word should be said about the different terminology used here, referring to "information regulation" instead of "reflexive law" ${ }^{49,50)}$. This paper focuses on a primary aspect of a reflexive legal model, namely, the importance of the production and use of information in regulation. However, "informational regulation" is both broader and narrower than "reflexive law." As discussed more fully below, one form of informational regulation can in fact be used for mandatory command-and-control purposes. A reflexive legal focuses on the internal operations within businesses and other intermediary social institutions and aims to instill "self-reflective" processes within them. Information is produced and used in this process, but it is not the primary focus of the theory. Here, we focus on the law and economics of informational regulation as a separate issue.

${ }^{8}$ For two more specific treatments of the role of information in environmental regulation, see Lyndon ${ }^{(4)}$ (discussing information strategy for toxics regulation) and Menell ${ }^{(46)}$ (discussing "ecoinformation policy" in consumer product labelling).

${ }^{9}$ Both specification-based and performance-based standards can be either static and forwardlooking or dynamic and backward-looking. Louis Kaplow ${ }^{(32)}$ distinguishes between "rules," which he defines as given ex ante, and "standards," which he defines as given ex post. This is an important distinction, and we attempt to capture the importance of the time horizon problem in making choices of regulation under the general category of "dynamic efficiency" as opposed to "static efficiency." (See infra section 5).

${ }^{10}$ Most environmental enforcement actions result in negotiated settlements. On negotiated rulemaking, see Harter ${ }^{(25)}$. Negotiated rulemaking is now required in certain contexts. Negotiated Rulemaking Act of 1990, 5 U.S.C. $\S \S 561-70$ (1994).

${ }^{11}$ Most countries follow a government-mandated eco-label system, e.g. Spindler ${ }^{(61)}$. The United States is an exception, and two private organizations currently compete for recognition in the ecolabel market, namely, Green Seal and Scientific Certification Systems ${ }^{(49)}$.

${ }^{12}$ An exception is what may be called "negative" environmental labelling, which mandates warnings to be given on labets of environmentally hazardous products.

${ }^{13}$ A parallel might be drawn to stock market trading information provided to the Securities and Exchange Commission for the purpose of enforcing laws against insider trading.

${ }^{14}$ Government oversight of process may involve a second-order specification-based standard. For further discussion of use of third parties in environmental regulation, see Er, Kunreuther \& Rosenthal ${ }^{(16)}$. For a description of the European Union's ambitious Eco-Management and Audit Scheme, which also employs third-party verification, see Orts ${ }^{(49)}$

${ }^{15}$ Negligence per se may be proven when a challenged action violates a statute, regulation, or municipal ordinance or when "it is so palpably opposed to the dictates of common prudence that it can be said without hesitation or doubt that no careful person would have been guilty of it." Black's 
Law Dictionary 933 (5th ed. 1979).

${ }^{16}$ Responsible Care has been described as one of "the most advanced new codes of environmental conduct" (Baram 1994: 47-49).

${ }^{17}$ We owe this terminology to our colleague, Irv Rosenthal.

${ }^{18}$ The EPA explicitly recognizes this economic approach to enforcement in its recent policy statement on environmental auditing, which provides incentives for self-reporting of legal violations. Incentives for Self-Policing: Discovery, Disclosure, Correction and Prevention of Violations, 60 Fed. Reg. 66, 706 (Dec. 22, 1995).

${ }^{19}$ For a recent discussion of the elements of IR in relation to local communities and social legitimation, see Ladeur $^{(40)}$.

${ }^{20}$ More generally these "losses" may be understood to be the negative of net benefits, which are to be maximized, as in Dasgupta et al ${ }^{(12)}$. Given our focus in this paper, the Shavell "expected cost" framework is more congenial for our purposes.

${ }^{21}$ For a more detailed discussion of this class of approaches in the context of environmental risks, $\operatorname{see}^{(35,17,9)}$.

${ }^{22}$ Thus, denoting the profit function of the company by $\mathrm{B}(\mathrm{Q}, \mathrm{Z})$ and the utility or welfare function of the community by $W(Q, Z)$, if we equip the company and the community with default options, a standard bargaining problem for $Q$ and $Z$ emerges. This problem can be informationally perturbed in various ways by an analysis of the information the company and the community have about $Q$ and $\mathrm{Z}$ and each other's benefit functions, with such information being represented as a "signal" that the company is required to reveal to the community about its operations.

${ }^{23}$ Concerning Eco-labels, see Spindler ${ }^{(61)}$. Concerning worst case scenarios, the recent hearings on the proposed regulation under section 112(r) of the Clean Air Act provide a case in point. A great deal of industry opposition to certain proposals concerning the communication of worst case scenarios was based on the belief that such scenarios would encourage communities to focus on very low probability events when the real benefits from risk reduction expenditures might well lie in other areas, such as decreasing the expected losses from an event (in contrast to worst case losses).

\footnotetext{
${ }^{24}$ For a formal analysis of this sort of complexity in the context of facility siting and management, see $^{(36)}$.

${ }^{25}$ See, e.g., the review in Crew and Kleindorfer ${ }^{(11)}$, chapter 7, and the discussion of "Goal-setting" in section 3 of Gruenspecht and Lave ${ }^{(17)}$.
} 
${ }^{26}$ Exactly this point on the diagnostic value of publicly available information is made in recent EPA discussion of IR (EPA, 1994).

${ }^{27}$ A theoretical framework for this is not difficult to specify. Signals arising from $\mathbb{R}$ would act as quality indicators for some market segment. Depending on their willingness to pay for the underlying quality attribute (in this case environmental performance), segment demand would shift in response to the IR-based signal of such quality. The market adjustment to such consumer tastes (including the company choices of "quality level") would be provided by standard of models of quality, as reviewed by Tirole ${ }^{(64)}$.

${ }^{28}$ Increasing effectiveness is not within the scope of the MLH analysis, since they assume a symmetric influence function for both industry and the public.

${ }^{29}$ The law of nuisance has existed for several centuries (see $\left.{ }^{(18,54)}\right)$. We omit, for present purposes, discussion of "public nuisance" cases that may be brought by the government. Historically, local government could bring actions to abate "public nuisances" that exhibited commons problems that private nuisance law did not reach. For the most part, contemporary law of "public nuisance" is statutory. $\left(\mathrm{See}^{(54)}\right)$.

${ }^{30}$ This account assumes a common law jurisdiction. A different account would be necessary for civil law countries. The account also oversimplifies the law of nuisance somewhat, but it is accurate for the general purpose here.

${ }^{31}$ For an extreme formulation of this constraint, see Epstein ${ }^{(15)}$.

${ }^{32}$ A partial exception appears in large class actions, in which individual parties may pool and share information. In large lawsuits, the media may also begin to take an interest in learning and disseminating information about particular disputes.

${ }^{33}$ For a discussion of federal statutes that give citizens and public interest groups rights to enforce federal environmental law and constitutional and procedural limitations on the "standing" of private citizens to do so, see ${ }^{(6,30,63)}$.

${ }^{34}$ For general evaluation of methods of regulation, see ${ }^{(11)}$; for environmental pollution and regulation, see ${ }^{(43)}$; for the legal foundations of risk regulation, see ${ }^{(7)}$; for the economics of risk regulation, $\operatorname{se}^{(53)}$.

${ }^{35}$ Allocative efficiency refers to least-cost input and technology choice for specified levels of output, and implies price of both inputs and outputs at marginal cost.

${ }^{36}$ As proposed by Harvey Leibenstein ${ }^{(41)}$, X-efficiency refers to the internal efficiency of a firm's operations and organizational procedures. Leibenstein noted that regulated firms in particular might not operate on the production frontier and that departures from frontier operations could be 
much more significant sources of inefficiency than missteps along the frontier

${ }^{37}$ See Williamson ${ }^{(66)}$. In the present context, transactions costs are generally understood to be the direct and indirect costs of dealing with the process of regulation, including paperwork, filings, etc., as opposed to organizational inefficiencies resulting from off-frontier operations, the latter being captured as $\mathrm{X}$-inefficiencies.

${ }^{38}$ For the current procedures adopted by the Clinton Administration, see Executive Order No. 12,866, 58 Fed. Reg. 51,735 (Sept. 30, 1993). A critical review of the procedures used by the Reagan, Bush, and Clinton Administrations is give in Shane ${ }^{(57)}$.

${ }^{39}$ For a discussion of legitimation issues in decision processes, see ${ }^{(37)}$.

${ }^{40}$ For a dense account of systemic legitimacy from the perspective of critical theory, see Habermas ${ }^{(19,20,21)}$. Systemic legitimacy may therefore differ in accordance with certain legal and political differences in particular countries. The legitimacy of international regulation would also require a more complex account, involving the questionable legitimacy of international law ${ }^{(51)}$. 
Figure 1

\section{Performance-Based and Specification-Based}

"Command and Control" Regulation
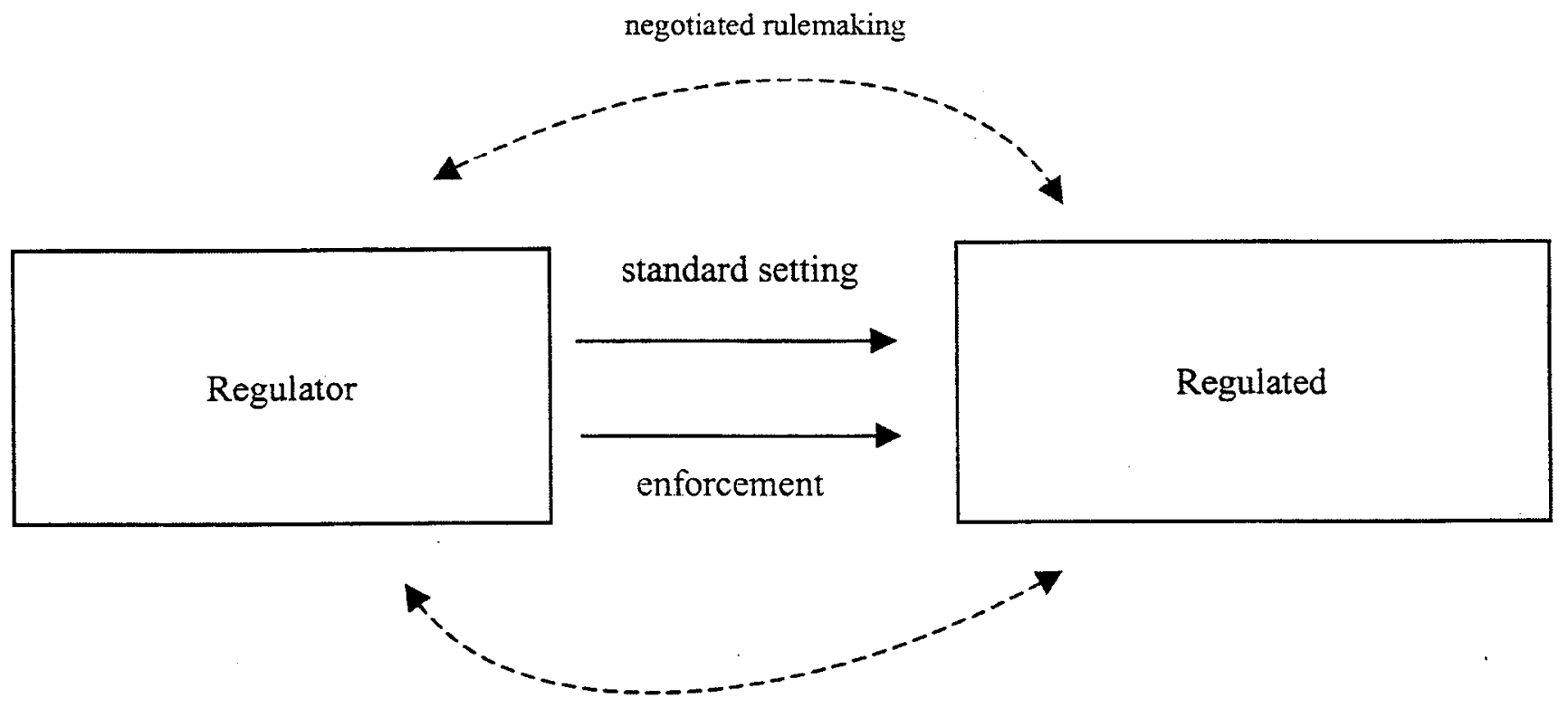

negotiated settlements 
Figure 2A

\section{Informational Regulation: Production of Information}

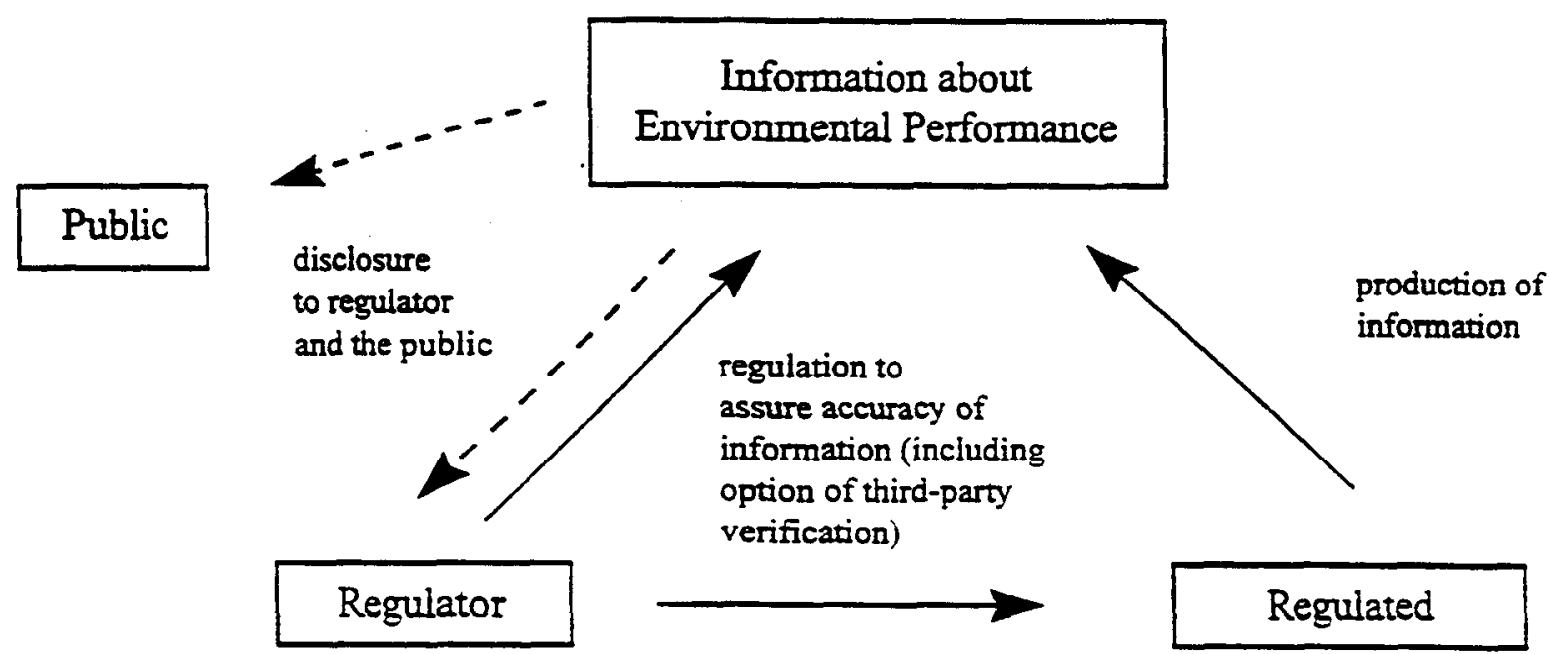

regulatory

incentives to produce

and disclose information 
Figure 2B

Informational Regulation: The Role of Standards

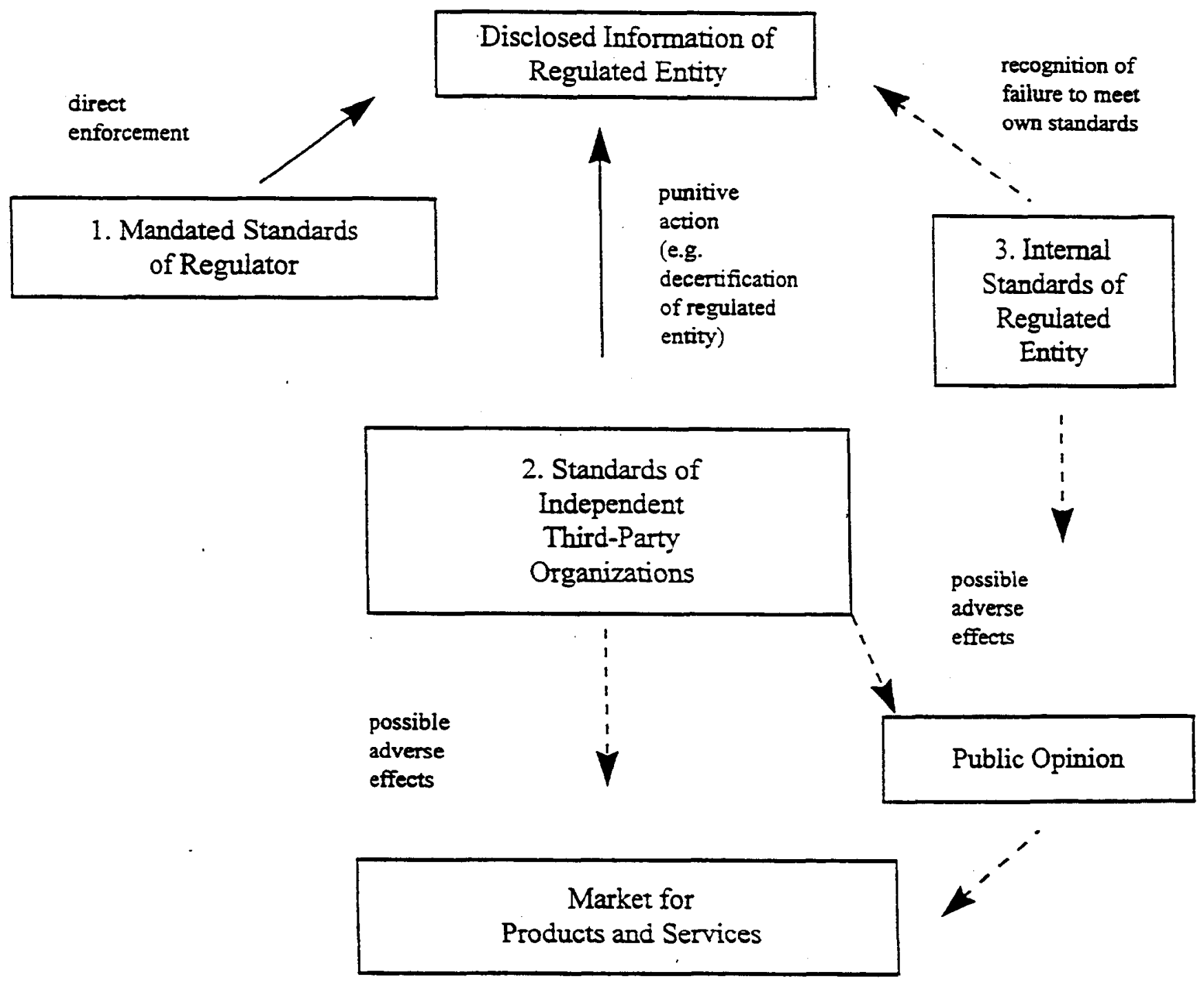


Figure3

Models of Environmental Regulation

\begin{tabular}{|c|c|c|c|}
\hline Private Rights & $\begin{array}{c}\text { Private litigation/ } \\
\text { dispute resolution }\end{array}$ & $\begin{array}{c}\text { Property rights; } \\
\text { Tort Law }\end{array}$ & Nuisance law \\
\hline Government-centered & $\begin{array}{c}\text { Administrative } \\
\text { enforcement }\end{array}$ & $\begin{array}{c}\text { Administratively } \\
\text { mandated and } \\
\text { hierarchically } \\
\text { imposed }\end{array}$ & $\begin{array}{c}\text { Command-and- } \\
\text { control statutes } \\
\text { and market-based } \\
\text { alternatives }\end{array}$ \\
\hline $\begin{array}{l}\text { Informational } \\
\text { Regulation }\end{array}$ & $\begin{array}{c}\text { Market and } \\
\text { public opinion } \\
\text { pressure }\end{array}$ & $\begin{array}{c}\text { Professional } \\
\text { organizations; } \\
\text { "best practice" }\end{array}$ & $\begin{array}{c}\text { Toxic Release Inventory, } \\
\text { risk management plans, } \\
\text { eco-labels }\end{array}$ \\
\hline
\end{tabular}

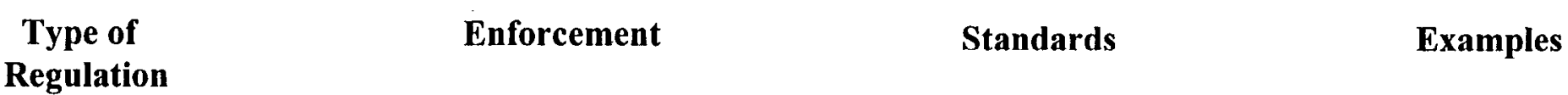


Figure 4

Prescriptive Evaluation of Regulations

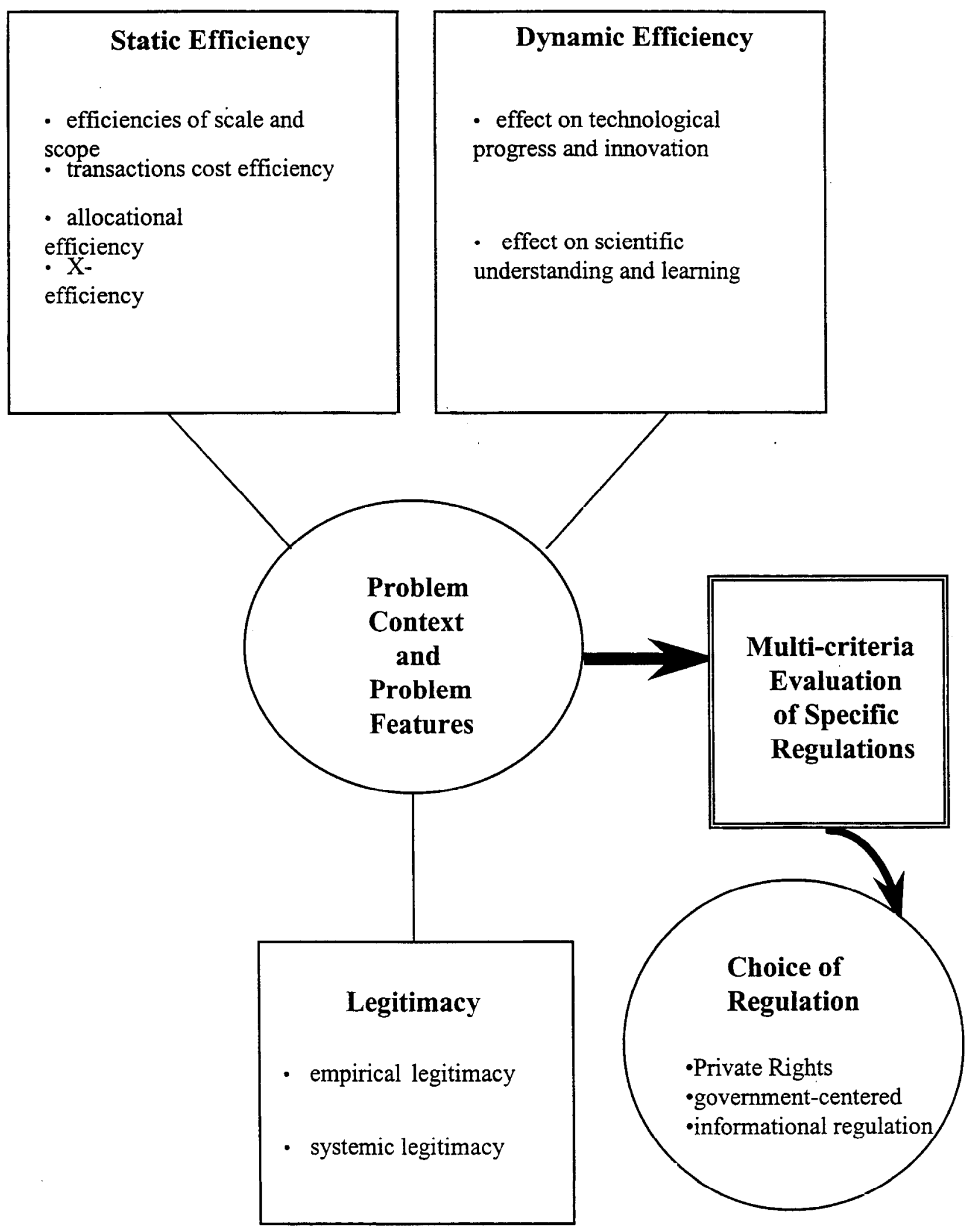

